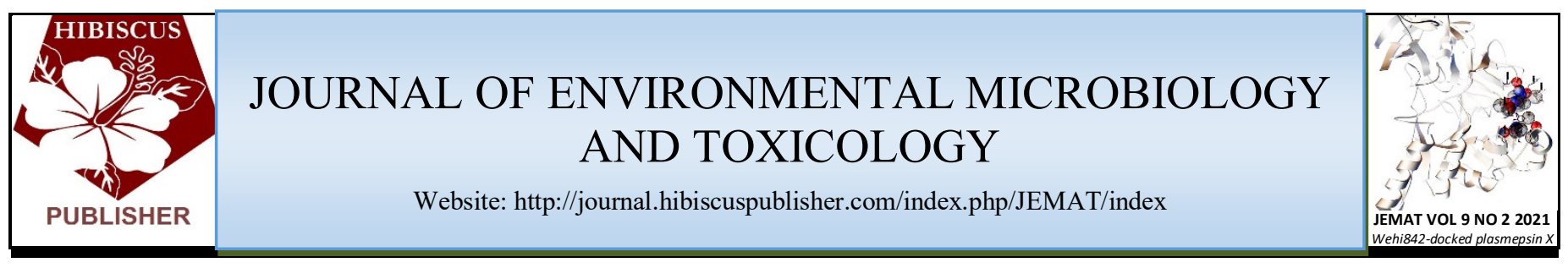

\title{
Isolation and Characterization of a PEG-degrading and Mo-reducing Escherichia coli strain Amr-13 in soils from Egypt
}

\author{
Nubli Shuhaimi ${ }^{1}$, AbdEl-Mongy, M. Abd. ${ }^{2}$, Shamaan, N.A. ${ }^{3}$, Lee Chaing Hin ${ }^{1}$, Syed, M.A. ${ }^{1}$ and M. Y. Shukor ${ }^{1 *}$ \\ ${ }^{1}$ Department of Biochemistry, Faculty of Biotechnology and Biomolecular Sciences, Universiti Putra Malaysia, UPM 43400 Serdang, \\ Selangor, Malaysia. \\ ${ }^{2}$ Microbial Biotechnology Department, Genetic Engineering and Biotechnology Institute, Sadat City University, Egypt. \\ ${ }^{3}$ Faculty of Medicine and Health Sciences, Universiti Sains Islam Malaysia, 55100 USIM, Kuala Lumpur, \\ Malaysia.
}

*Corresponding author:

Yunus Shukor,

Department of Biochemistry,

Faculty of Biotechnology and Biomolecular Sciences,

Universiti Putra Malaysia,

UPM 43400 Serdang,

Selangor,

Malaysia.

Email: yunus.upm@gmail.com, mohdyunus@upm.edu.my

\section{HISTORY}

Received: $15^{\text {th }}$ Sep 2021

Received in revised form: $24^{\text {th }}$ Nov 2021

Accepted: $20^{\text {th }}$ Dec 2021

\section{KEYWORDS}

PEG-degrading

Molybdenum reduction

Molybdenum blue

Escherichia coli

Bioremediation

\begin{abstract}
Molybdenum is a pollutant that shows toxicity to spermatogenesis while polyethylene glycols (PEG) are used predominantly in detergents. The pollution of molybdenum and PEGs are reported worldwide. We have isolated ten molybdenum-reducing bacterial isolates from soil that can reduce molybdenum (sodium molybdate) into the colloidal molybdenum blue (Mo-blue). The screening of these isolates for PEG-degrading ability showed that one isolate was capable to utilize PEG 200, 300 and 600 for optimal conditions were $\mathrm{pHs}$ between 5.5 and 8.0, temperatures between 30 and $37^{\circ} \mathrm{C}$, phosphate at $5 \mathrm{mM}$, molybdate between 10 and $30 \mathrm{mM}$, and glucose as the electron donor. Biochemical analysis of the bacterium identifies it as Escherichia coli strain Amr-13. Growth was best supported by all PEGs at concentrations of between 600 and 1,000 $\mathrm{mg} / \mathrm{L}$. A complete degradation for PEG 200 and PEG 300 at $1,000 \mathrm{mg} / \mathrm{L}$ was observed on day four and five, respectively, while nearly $90 \%$ of PEG 600 was degraded on day six. The growth of this bacterium on these PEGs was modelled using the modified Gompertz model, and produced growth parameters values, which were maximum specific growth rates of $1.51,1.45$ and $1.18 \mathrm{~d}^{-}$ ${ }^{1}$ and lag periods of $0.53,0.87$ and 1.02 day for PEG 200, PEG 300 and PEG 600, respectively. PEG 200 was the most preferred substrate for this bacterium, while PEG 600 was the least preferred.
\end{abstract}

\section{INTRODUCTION}

The principal usage of molybdenum is in the steel and alloy industries. Molybdenum contamination from manufacturing exercise has generated pollution in water bodies and soils. Marine environments from the Black Sea and Japan Bay are polluted with molybdenum at concentration exceeding beyond requirements of regulatory authorities [1]. Molybdenum emitted by industrial fumes in Tyrol, Austria has polluted agricultural areas over several years. The hazards of this action was only appreciated when cows grazing the land became ill and deaths reported [2]. Metals prospecting locations are further important causes of molybdenum toxic contamination. In New Mexico, concentrations of dissolved molybdenum as high as $900 \mathrm{mg} / \mathrm{L}$ have been documented in the tailing waters from a molybdenum mine [3]. Within the same location, molybdenum concentration up to $2000 \mathrm{ppm}$ or $20.8 \mathrm{Mm}$ is discovered in soils [4]. From a molybdenum mine in western Liaoning, China, tailings waste materials have brought on the molybdenum concentrations in several locations of the Nver River sediment to exceed the regulatory limits by more than a few hundred times posing a bad risk towards the regional ecosystem [5]. In Egypt molybdenum levels above the regulatory limit has been discovered in mackerel fish caught in the neighbouring seas, possibly a result from human industrial activities [6]. Based on recent data, molybdenum is discovered to inhibit spermatogenesis and arrest embryogenesis in many terrestrial and aquatic organisms [7-9]. Hence, molybdenum removal from the environment is being intensely researched. Bioremediation is a viable and cheaper approach to molybdenum bioremoval. Mo-reducing bacteria are on of such candidates for bioremediation, and several have been isolated [10-12]. 
Polyethylene glycols are used in many industries such as cosmetics, lubricants, pharmaceuticals, and antifreeze for automobile radiators and in the production of non-ionic surfactants. Millions of tonnes of PEG are produced yearly, and their contamination of aquatic sediments in rivers and seas have been reported. In mammalians, PEG can act as a parasympathomimetic-like compound. Wounded rabbit exposed topically to polyethylene glycol-based antimicrobial cream model showed evidence of nephrotoxicity with symptoms of failure. Several of the animals tested died within one week of therapy [13][14]. Intravenous feed showed that PEG results in blood clot and leads to clumping of cells and even death through embolism.

Absorption of PEG can lead to fatal toxic syndrome, and this has been suggested due to the formation of mono- and dicarboxylated forms of PEG [13]. PEGs-tainted effluents are a major polluter in traditional sewage treatment systems [15]. PEGs are generally recalcitrant for degradation especially in water sediments with $5 \mathrm{mg} / \mathrm{L}$ of PEGs up to PEG 400 requiring nearly 170 days for complete biodegradation under anaerobic conditions [14]. Biodegradation of PEG was first documented in 1965 [16] and further isolations of PEG-degrading microorganisms have been reported [14,17-25].

The presence of both heavy metals and xenobiotics in industrial effluents presents a significant barrier to bioremediation. The hunt for a microorganism with a wide range of heavy metal and xenobiotic detoxifying capabilities is one of the most active endeavours now underway. Keeping this in mind, the goal of this study is to discover a microbe capable of detoxifying heavy metals, using molybdenum as the model metal. Despite molybdenum being a hazardous metal, little study has been done on the process of molybdenum detoxification. A molybdenum-reducing bacteria capable of growing on several PEGs has been reported in this study. In order to accurately predict the development of this bacteria on PEGs, the modified Gompertz model was used. Both the heavy metal molybdenum and PEGs, as organic contaminants, are well-suited for bioremediation using this bacterium's numerous detoxifying potentials.

\section{MATERIALS AND METHODS}

\section{Soil sampling}

During a 2014 field study in Sadat City, Egypt, soil samples were collected from the grounds of a contaminated site (auto repair workshop). Using a sterile big steel spatula, soil (ten grammes) was removed from the topsoil about $5 \mathrm{~cm}$ below the surface and placed in a sterile polycarbonate container for storage.

\section{Mo-reducing bacteria media}

Minimum salts medium (MSM) and sodium molybdate (LPM) medium were used to isolate molybdenum-reducing bacteria from soils. Initially, a soil suspension was created by combining $1 \mathrm{~g}$ of earth with $10 \mathrm{~mL}$ of deionized water and stirring it thoroughly. Soil microorganisms cannot be harmed by deionized water because of osmotic effects due to the high organic content of the soil. It was then transferred to an agar-coated plate, where it was incubated for a few $\mathrm{h}$ before being transferred to a new plate $(0.1 \mathrm{~mL})$. The medium $(\mathrm{w} / \mathrm{v})$ at $\mathrm{pH} 6.5$, with the composition as follows: $\mathrm{Na}_{2} \mathrm{MoO}_{4} \cdot 2 \mathrm{H}_{2} \mathrm{O}(0.242 \%$ or $10 \mathrm{mM})$, $\mathrm{NaCl}(0.5 \%)$, agar (1.5\%), $\mathrm{MgSO}_{4} \cdot 7 \mathrm{H}_{2} \mathrm{O}(0.05 \%)$, glucose $(1 \%)$, yeast extract $(0.5 \%),\left(\mathrm{NH}_{4}\right)_{2} \cdot \mathrm{SO}_{4}(0.3 \%)$, and $\mathrm{Na}_{2} \mathrm{HPO}_{4}(0.071 \%$ or $5 \mathrm{mM}$ ) [12]. The plate was covered with many white and blue colonies that emerged after $48 \mathrm{~h}$ of incubation at room temperature. It was necessary to transfer ten blue isolates onto another LPM agar plate several times in order to purify the isolate before screening it for growth on various PEGs.

\section{Quantification of Mo-blue production}

The determination of mo-blue was carried out in a $100 \mathrm{~mL}$ liquid culture of LPM bacteria. This was done in order to identify the most effective isolate. The best isolate was selected using an extinction coefficient of $11.69 \mathrm{mM}$.-1.cm-1 at $750 \mathrm{~nm}$ [12].

Identification of bacterium through biochemical analysis This study was carried out in accordance with the Bergey's Manual of Determinative Bacteriology, using phenotypical and biochemical methods, and the results were entered into the ABIS online system, as was done previously [12].

\section{Resting cells preparation for Mo-blue production characterization}

As before, the preparation of resting cells was carried out [26]. On an orbital shaker $(120 \mathrm{rpm})$ at $28^{\circ} \mathrm{C}$, the bacteria were grown in 1 litre of high phosphate molybdate media (HPM) for $48 \mathrm{~h}$. Mo-blue colloidal particles, however, induced cells in the LPM to aggregate, resulting in a $100 \mathrm{mM}$ concentration in the HPM. Deionized water was used to wash the cells twice before they were resuspended in LPM media, as described in the preceding section of this article (glucose omitted initially). A sterile microplate was used to distribute the produced cell suspension $(180 \mu \mathrm{L})$ and incubate it for $30 \mathrm{~min}$. Mo-blue was formed by adding sterile glucose $(20 \mu \mathrm{L})$ from a $10 \%(\mathrm{w} / \mathrm{v})$ stock solution to the cell suspension. Sterile sealing tape was applied to the Corning ${ }^{\circledR}$ microplate to allow for gas exchange. The microplate's temperature was maintained at room temperature. Model 680 of BioRad's microtiter plate reader was used to measure Mo-blue production at $750 \mathrm{~nm}$. It was found that the Mo-blue concentration could be accurately measured by using the specific extinction value of $11.69 \mathrm{mM}^{-1} \mathrm{~cm}^{-1}$ [27].

\section{PEGs as carbon sources for growth}

Initial results suggest that none of the PEGs were able to support molybdenum reduction; as a result, the PEGs will be tested for their ability to sustain the growth of the isolated strains. Using the microplate format and the growth media described above, the ability of polyethylene glycols such as PEG 200, PEG 300, PEG 600 and so on to support growth was investigated using the PEGs at a final concentration of $1,000 \mathrm{mg} / \mathrm{L}$ in a final volume of $250 \mathrm{~L}$, with PEGs in the final volume of $250 \mu \mathrm{L}$. The microplate format specified above was used to analyse the results.. The medium was composed of the following components: $\mathrm{NaNO}_{3}(0.2$ percent $)$, $\left(\mathrm{NH}_{4}\right)_{2} \bullet \mathrm{SO} 4\left(0.3\right.$ percent), yeast extract $(0.01 \%), \mathrm{MgSO}_{4} \bullet 7 \mathrm{H}_{2} \mathrm{O}$ (0.05 percent), $\mathrm{Na}_{2} \mathrm{HPO}_{4}(0.705$ percent or $50 \mathrm{mM}), \mathrm{NaCl}(0.5$ percent), and one millilitre of trace elements solution. The $\mathrm{pH}$ of the growth medium was 7.0. The trace elements $(\mathrm{mg} / \mathrm{L})$ was as follows: $\mathrm{FeSO}_{4} \cdot 7 \mathrm{H}_{2} \mathrm{O}(40), \mathrm{CaCl}_{2}(40), \mathrm{MnSO}_{4} \cdot 4 \mathrm{H}_{2} \mathrm{O}$ (40), $\mathrm{CuSO}_{4} \cdot 5 \mathrm{H}_{2} \mathrm{O} \quad(5), \quad \mathrm{ZnSO}_{4} \cdot 7 \mathrm{H}_{2} \mathrm{O} \quad(20), \mathrm{Na}_{2} \mathrm{MoO}_{4} \cdot 2 \mathrm{H}_{2} \mathrm{O}$ $\mathrm{CoCl}_{2} \bullet 6 \mathrm{H}_{2} \mathrm{O}$ (5), [12]. At $600 \mathrm{~nm}$, the microplate reader was used to monitor the development of bacteria for five days at room temperature $\left(28^{\circ} \mathrm{C}\right)(\mathrm{Bio}-\mathrm{Rad} 680)$.

\section{PEG degradation assay}

At a concentration of $10 \mathrm{mg} / \mathrm{L}$, the stock solutions of several PEGs were produced. The combination had a total capacity of 2 $\mathrm{mL}$ and was composed of stock solutions of various PEGs that had been stably diluted to achieve a final concentration ranging from 1 to $7.5 \mathrm{mg} / \mathrm{L}$, depending on the PEG. Before adding the samples from the resting cells preparation to the assay reagents, they were appropriately diluted. During the first incubation period and after an extensive incubation time of 10 days at $28^{\circ} \mathrm{C}$, samples were collected. The colorimetric reagents comprise of a 
solution of $5 \%(\mathrm{w} / \mathrm{v}) \mathrm{BaCl}_{2} \mathrm{H}_{2} \mathrm{O}$ in $1 \mathrm{M} \mathrm{HCl}(200 \mu \mathrm{L})$ mixed with another $200 \mu \mathrm{L}$ of a solution of $1.27 \mathrm{~g}$ iodine that was first dissolved in $100 \mu \mathrm{L}$ of $2 \%(\mathrm{w} / \mathrm{v})$ potassium iodide. The mixture was incubated at room temperature $\left(28{ }^{\circ} \mathrm{C}\right)$ for $10 \mathrm{~min}$ of incubation and the color was measured at $535 \mathrm{~nm}$ in comparison to a reagent blank with water as a reference point. The concentration of PEG was evaluated by observing the intensity of brownish orange hue produced by the complex solution during the experiment. This is a sensitive, straightforward approach that can be used to any PEG compounds [28].

PEG degradation percentage of (Eqn. i) was calculated as:

$\% \mathrm{PEG}$ degradation $=\left[1-\left([\mathrm{PEG}] t_{f}[\mathrm{PEG}] t_{i}\right)\right] \times 100 \%$

Where $[\mathrm{PEG}] t_{f}=\mathrm{PEG}$ concentration at the time of final incubation, and $[\mathrm{PEG}] t_{i}=\mathrm{PEG}$ concentration at the time of initial incubation.

\section{Mathematical modelling of growth on PEG}

Bacterial growth on PEG was modeled using the modified Gompertz model (Eqn. ii) [29]. The absorbance values determined at $600 \mathrm{~nm}$ was first converted to natural logarithm.

$y=A \exp \left\{-\exp \left[\frac{\mu_{m} e}{A}(\lambda-t)+1\right]\right\}$

where $A=$ bacterial growth at lower asymptote; $\mu_{m}=$ maximum specific bacterial growth rate, $\lambda=$ lag time, $e=$ exponent (2.718281828) and $t=$ sampling time.

$$
\begin{gathered}
\text { Adjusted }\left(R^{2}\right)=1-\frac{s_{y}^{2}}{s_{Y}^{2}} \\
\text { Adjusted }\left(R^{2}\right)=1-\frac{\left(1-R^{2}\right)(n-1)}{(n-p-1)}
\end{gathered}
$$

\section{RESULTS AND DISCUSSIONS}

Molybdenum reduction to molybdenum blue has been observed in a river that turns blue. The river runs through molybdenumrich contaminated soils [30]. Bacterial reduction of molybdate to Mo-blue by was first mentioned more than a century ago in the year 1896 [31]. Further reports are scarce. For example, the next immediate report is by Jan in 1939 [32]. Intermittent reports [3337] on microbiological reduction of molybdenum to molybdenum blue from the works of Jan until the year 2000 highlighted the scarcity of information on this phenomenon. The earliest most comprehensive works on this phenomenon were carried out by Campbell et al. in the bacterium Eschericia coli K12. It was Ghani et al. [35] who are fast to notice the possible applicability of this event for molybdenum bioremediation of molybdenum contamination.
Table 1. Characterization of some of the Mo-reducing bacteria isolated to date.

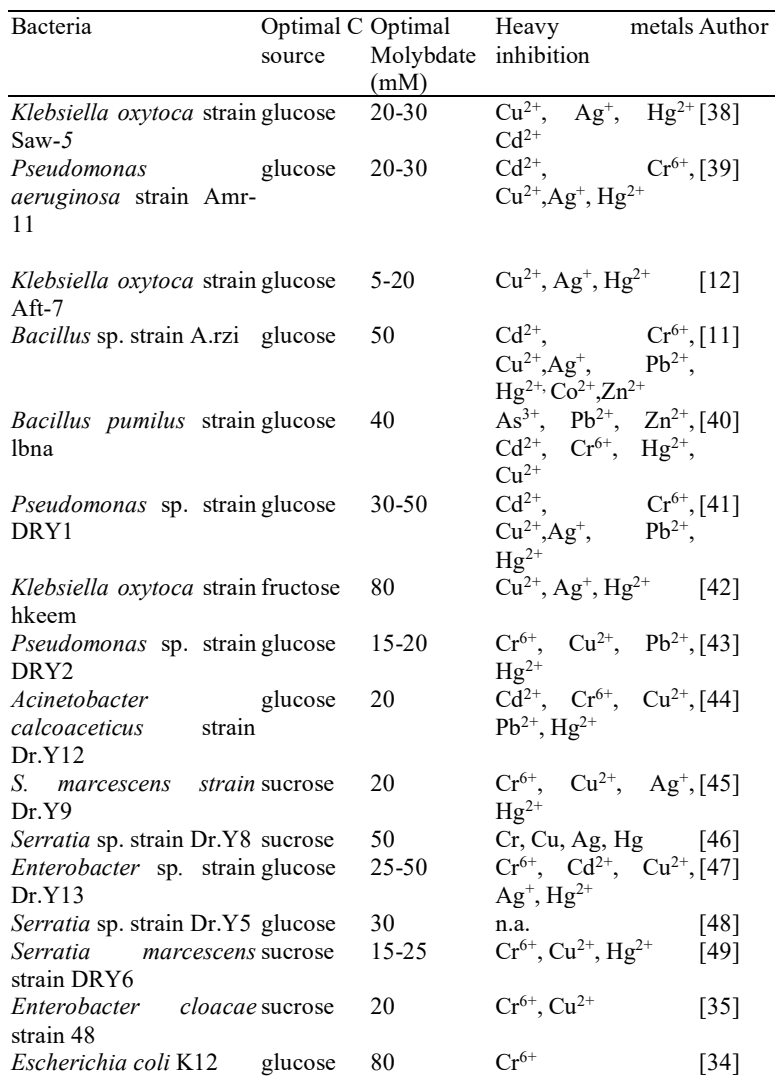

Identification of molybdenum reducing bacterium

Ten Mo-reducing bacterial candidates were identified, with isolate I being the best candidate based on the amount of Mo-blue it produced. Nonetheless, screening for potential PEG-degrading capability among the Mo-reducing bacteria reveals that isolate B can only weakly grow on PEG 200, isolate $\mathrm{H}$ can only grow on PEG 300 at medium strength, and isolate $\mathrm{E}$ is the best because it can degrade PEG 200, PEG 300, and PEG 600. Isolate E is the best because it can degrade PEG 200, PEG 300, and PEG 600 . The isolate in question was chosen for further investigation.

The bacterium was motile, had a rod-like appearance, and was a facultative anaerobic and Gram-negative bacterium, according to the findings. The colonies were between one and three millimeters in size and had a shiny, smooth, cream white, round look. The ABIS online program was used to execute the various biochemical tests (Table 2) that were obtained. The software offers Escherichia coli as the bacterial identity because it has the highest homology score (>90 percent) and the best accuracy score (100 percent) of all the bacteria tested. Although this is true, the moniker is just temporary until the bacterium can be accurately identified through molecular analysis of the 16srRNA gene. The bacterium has been identified as Escherichia coli strain Amr-13 for the time being. A previous report have shown the ability of bacterium from this species to reduce molybdenum to molybdenum blue [34] and to weakly degrade PEG-200 [19]. 
Table 2. Mo-blue production by bacterial isolates measured at $750 \mathrm{~nm}$, and growth on various PEGs measured at $600 \mathrm{~nm}$. Strength of bacterial growth on PEG was indicated using $\mathrm{X}, \mathrm{XX}$ and $\mathrm{XXX}$, which indicate growth of between 0.1 to 0.2 , between 0.2 and 0.3 and $>0.3$ absorbance units, respectively, measured at $600 \mathrm{~nm}$.

\begin{tabular}{lllllll}
\hline Isolate & $\begin{array}{l}\text { A } 750 \\
\text { deviation, } \mathrm{n}=3) .\end{array}$ & & & & \\
\hline $\mathrm{A}$ & 0.42 & \pm & \pm .04 & - & - & - \\
$\mathrm{B}$ & 0.24 & \pm 0.01 & $\mathrm{X}$ & - & - \\
$\mathrm{C}$ & 0.96 & \pm 0.04 & - & - & - \\
$\mathrm{D}$ & 0.92 & \pm 0.12 & - & - & - \\
$\mathrm{E}$ & 1.01 & \pm 0.05 & $\mathrm{XXX}$ & $\mathrm{XXX}$ & $\mathrm{XXX}$ \\
$\mathrm{F}$ & 0.53 & \pm 0.01 & - & - & - \\
$\mathrm{G}$ & 1.24 & \pm 0.08 & - & - & - \\
$\mathrm{H}$ & 0.97 & \pm 0.06 & - & $\mathrm{XX}$ & - \\
$\mathrm{I}$ & 1.97 & \pm 0.06 & - & - & - \\
$\mathrm{J}$ & 0.10 & \pm & 0.05 & - & - & -
\end{tabular}

Table 1. Biochemical tests for Escherichia coli strain Amr-13.

\begin{tabular}{lcll}
\hline Motility & + & Acid production from: & \\
\hline Pigment & - & & \\
ONPG (beta-galactosidase) & + & L-Arabinose & + \\
Catalase production $(24 \mathrm{~h})$ & + & Alpha-Methyl-D-Glucoside & - \\
Ornithine decarboxylase (ODC) & + & Glycerol & + \\
Oxidase (24 h) & - & D-Adonitol & $\mathrm{d}$ \\
Lysine decarboxylase (LDC) & + & Dulcitol & + \\
Arginine dihydrolase (ADH) & $\mathrm{d}$ & Cellobiose & - \\
Methyl red & + & myo-Inositol & - \\
Nitrates reduction & + & D-Glucose & + \\
Indole production & + & Maltose & + \\
Voges-Proskauer (VP) & - & Lactose & + \\
Acetate utilization & + & D-Mannose & + \\
Hydrogen sulfide (H2S) & $\mathrm{d}$ & D-Mannitol & + \\
Citrate utilization (Simmons) & - & Mucate & + \\
Malonate utilization & - & Melibiose & + \\
Esculin hydrolysis & + & L-Rhamnose & + \\
Tartrate (Jordans) & + & Raffinose & + \\
Urea hydrolysis & - & D-Sorbitol & + \\
Gelatin hydrolysis & - & Salicin & + \\
Lipase (corn oil) & - & Trehalose & + \\
Deoxyribonuclease & $\mathrm{d}$ & Sucrose & + \\
Phenylalanine deaminase & $\mathrm{d}$ & D-Xylose & + \\
Note: indeterminate result, + positive result, - negative result &
\end{tabular}

The use of a microplate format can speed up Mo-reduction characterization and screening works [26], while washed, whole or resting cells have been used in studying xenobiotic detoxifications including molybdenum reduction [35] and pentachlorophenol degradation [50]. Mo-blue production was optimum between 34 to $37^{\circ} \mathrm{C}$ (Data not shown) and between $\mathrm{pH}$ 5.8 and 6.8 (data not shown).

\section{Carbon sources as potential electron donor to Mo-blue production}

The sugar glucose was shown to be the most effective electron donors for enabling Mo-blue synthesis, followed by sucrose, dmannose, lactose, melibiose, maltose, trehalose, l-rhamnose, larabinose, myo-Inositol, and d-mannose, all in descending order of effectiveness (Fig. 5). The ideal concentration of glucose was 1 percent $(\mathrm{w} / \mathrm{v})$, with higher quantities limiting the synthesis of Mo-blue. (data not shown). Glucose inhibition at concentrations above $1 \%(\mathrm{w} / \mathrm{v})$ is also reported in several Mo-reducing bacteria, and this is likely due to the osmotic stress caused by high concentrations of glucose $[12,47]$.
Either glucose or lactate, and sometimes formate are the best electron donor supporting metal bacterial reductions, which includes arsenate [51], and chromate [52]. As far as Mo-reducing bacteria is concern, nearly all either prefer glucose or sucrose (Table 1). This is because the Mo-reducing enzyme requires $\mathrm{NADH}$ or NADPH as electron-donating substrates, and both sucrose and glucose can produce these compounds via generic pathways $[35,53,54]$, thus explaining the preference observed. Some metal reduction works have concentrated upon cheaper substrate such as molasses [55,56], and current works are being carried out the possibility of using this substrate as a cheaper alternative.

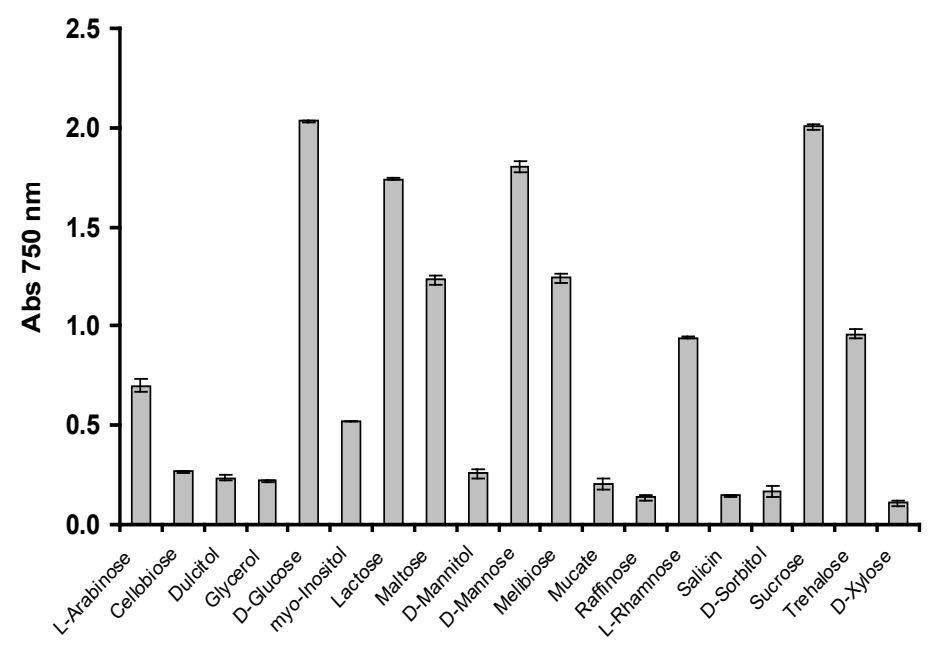

Fig. 5. The effect of various carbon sources as potential electron donor sources $(1 \% \mathrm{w} / \mathrm{v})$ for Mo-blue production. The error bars are average \pm standard deviation of triplicates.

\section{The effect of sodium molybdate concentrations to Mo-blue production}

The optimal sodium molybdate concentration was found to be between 10 and $30 \mathrm{mM}$ while studying its effect on Mo-blue synthesis (Fig. 6). The ideal concentration range is between 5 and $80 \mathrm{mM}$, which has been found in previously identified Moreducing bacteria (Table 1). Anionic heavy metals, in contrast to cationic heavy metals, can be tolerated and reduced by bacteria at high concentrations. For instance, the most tolerant microorganism can tolerate and reduce selenate at $20 \mathrm{mM}$ in Bacillus sp. [57], chromate at $30 \mathrm{mM}$ in Pseudomonas putida [52], vanadate at $50 \mathrm{mM}$ in Pseudomonas isachenkovii [58] and arsenate at $60 \mathrm{mM}$ in Citrobacter sp. NC-1 [51] . Because these bacteria exhibit the capacity to reduce molybdenum at unusually high concentrations, this implies that molybdenum is not toxic to the Mo-reducing bacteria. The concentrations of molybdenum in waters and soils have been reported to reach up to $900 \mathrm{mg} / \mathrm{L}$ and $6,500 \mathrm{mg} / \mathrm{Kg}$, respectively [59]. Even at these high concentrations of molybdenum as a pollutant, these bacteria are good instruments for bioremediation. Another important requirement is the phosphate concentrations in soil and water should be close to $5 \mathrm{mM}$ or should not exceed $20 \mathrm{mM}$ for reduction to occur. Fortunately, phosphate concentrations are not found in concentrations above these range in typical water bodies or soils [60]. 


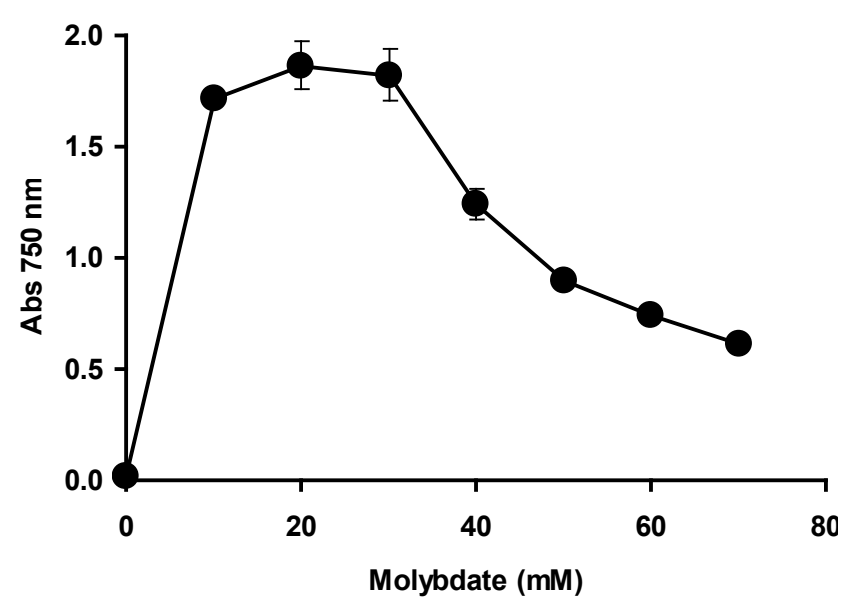

Fig. 6. Mo-blue production at various sodium molybdate concentrations. The error bars are average \pm standard deviation of triplicates.

\section{PEGs as carbon sources for growth}

Growth of this bacterium on PEG 200, 300 and 600 was examined in the range of 100 to $1200 \mathrm{mg} / \mathrm{L}$ at various $\mathrm{PEG}$ concentrations. Concentrations between 600 and $1,000 \mathrm{mg} / \mathrm{L}$ of all PEGs were shown to be the most favourable for growth. Growth was marginally inhibited by PEGs at higher concentrations (Fig. 7). All PEGs showed a one-day lag period in degradation testing. Nearly 90 percent of PEG 600 degradation occurred on day six, while PEG 200 and PEG 300 decayed completely on day four and five, respectively (Fig. 8). To predict bacterial growth on these PEGs at $1,000 \mathrm{mg} / \mathrm{L}$, a modified Gompertz model was used (Fig. 9). PEG 200, PEG 300, and PEG 600 had maximal specific growth rates of $1.510 .06,1.450 .05$, and $1.180 .04 \mathrm{~d}-1$, although $90 \%$ of PEG 600 deteriorated by day six (Fig. 10). There was a lag time of $0.530 .06,0.870 .04$ and 1.020.04 for PEG 200, PEG 300 and PEG 600, respectively. PEG 200, PEG 300, and PEG 600 all had adjusted coefficient of determinations (adjR2) of 0.995 to 0.995 , suggesting good agreement between the anticipated and observed values. While PEG 600 was the least preferred substrate for this bacterium, it had the highest specific growth rate and lowest lag duration of all the substrates. It has also been seen in other bacterial studies of PEG breakdown, and the length of the lag time ranges from one to two days in aerobic circumstances and more than ten days in anaerobic ones [14,21].

Xenobiotics and heavy metals detoxifying bacteria are rarely documented. There were few cases. As an example, in chromate reduction, an electron donor such as phenol could be utilized [61]. Because this bacteria can metabolize PEG and reduce molybdenum, its bioremediation potential is regarded unique and helpful. According to search databases, short PEG chains $(1,000)$ are more biodegradable than longer chains $(5,000)$. PEG-degrading monocultures with longer PEG chains (PEG 20,000) are extremely unusual, with only a handful known to exist $[62,63]$. As a result, PEGs with longer carbon chains degrade more slowly than PEGs with shorter chains of carbon. Anaerobic degradation of chains longer than PEG 10,000 takes hundreds of days, while aerobic degradation occurs when bacterial co-culture is present [18].
When PEG (PEG 400) biodegraded for the first time, it occurred in 1962 [64]. Under aerobic conditions, the primary enzymes that degrade PEG are alcohol dehydrogenase, aldehyde dehydrogenase, and an ether-bond-splitting enzyme that converts PEG to carboxylic acid groups and eventually to the Kreb's cycle bypass metabolite glyoxylate (GOA). PEG absorption by microorganisms appears to begin with the production of this metabolite. For example, glyoxylate shunt can be used to bypass Krebs' cycle and feed into other anabolic pathways without going through the Krebs cycle [18,24,62,65-67]. Heavy metal detoxifying bacteria and xenobiotic degrading bacteria are rarely reported. Few samples were available. It's possible to employ an electron donor like this in the reduction of chromate, for example. It is therefore deemed new and valuable for bioremediation since this bacterium has the ability to breakdown PEG and decrease molybdenum.

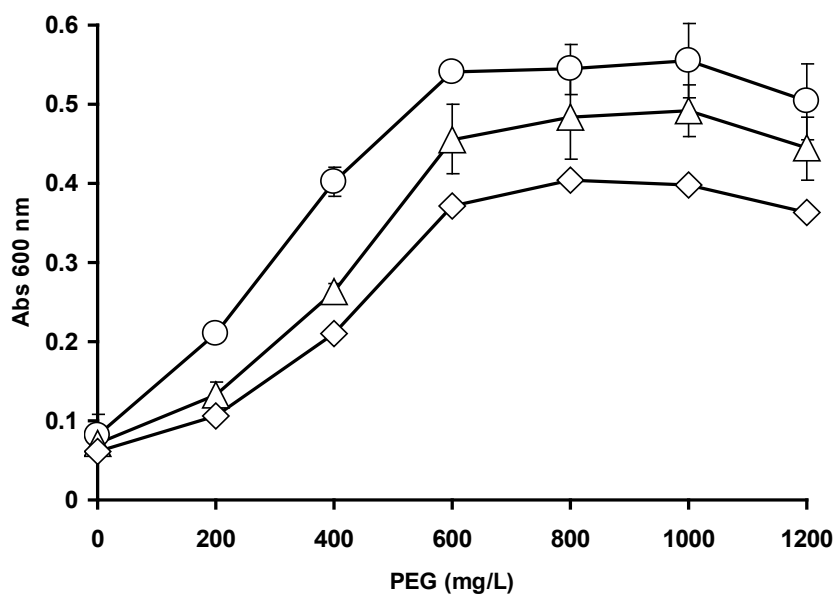

Fig. 7. Growth of Escherichia coli strain Amr-13 on PEG $200(\bigcirc), 300$ $(\triangle)$ and $600(\diamond)$. The error bars are average \pm standard deviation of triplicates.

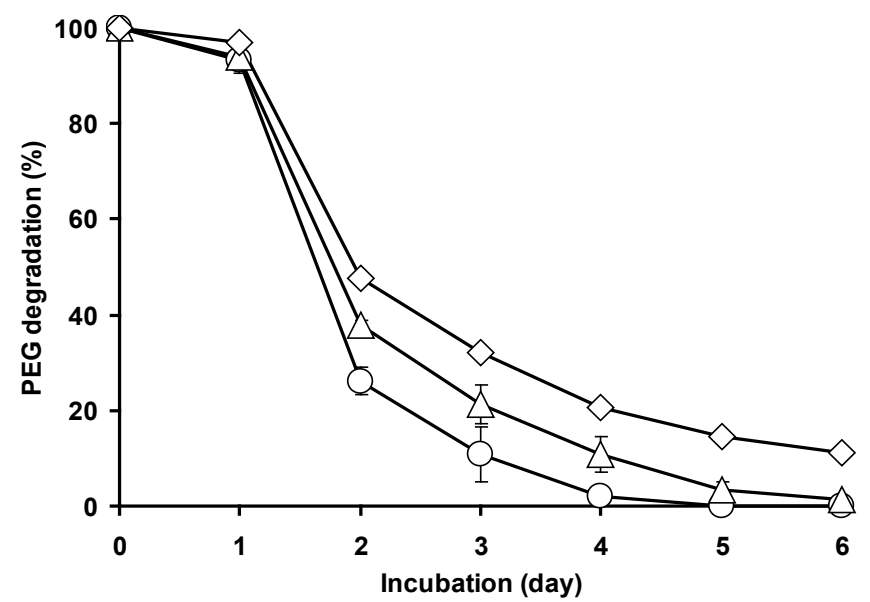

Fig. 8. Degradation of $1,000 \mathrm{mg} / \mathrm{L}$ of PEG $200(\mathrm{O}), 300(\triangle)$ and 600 $(\diamond)$ by Escherichia coli strain Amr-13. PEG degradation was monitored according to the assay. The error bars are average \pm standard deviation of triplicates. 


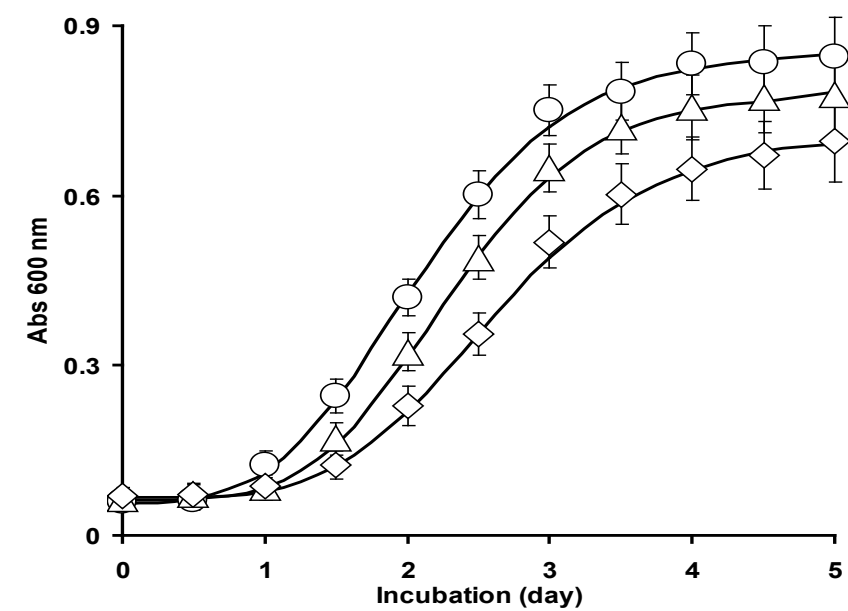

Fig. 9. Escherichia coli strain Amr-13 growth on 1,000 mg/L of PEG 200 $(\bigcirc), 300(\triangle)$ and $600(\diamond)$ as modelled using the modified Gompertz model (solid lines). The error bars are average \pm standard deviation of triplicates.

\section{CONCLUSION}

Molybdenum is a new worldwide contaminant that has been discovered to be extremely harmful to spermatogenesis in animal studies just lately. These bacteria will be isolated from soil and tested for their ability to degrade polyethylene terephthalate (PEG). It has been discovered that a Mo-reducing bacterium can utilise PEG 200, 300, and 600 as carbon sources for growth. A molybdenum-degrading activity with PEG-degrading ability has never been reported before. This bacterium's Mo-blue production has been characterised, and the results are consistent with prior findings. Two of the PEGs examined completely degraded after five days of incubation, according to studies. Finally, growth of these bacteria on PEG was simulated using the modified Gompertz model, and important growth characteristics indicated that PEG 200 was the optimal substrate. The use of a modified Gompertz model for PEG is new to our knowledge. Partially identifying the microorganism as Escherichia coli strain Amr-13 was a promising first step. The 16s rRNA gene is being sequenced as part of a new identification effort, which will be followed by molecular phylogenetic analysis. It is being purified and the PEG-degrading capacity of the molybdenum-reducing enzyme from this bacterium is being studied. The capacity of this bacteria to detoxify PEG and molybdenum, two of the most resistant contaminants, is helpful for bioremediation.

\section{REFERENCES}

1. Davis GK. Molybdenum. In: Merian E, editor. Metals and their Compounds in the Environment, Occurrence, Analysis and Biological Relevance. VCH Weinheim, New York; 1991. p. 1089100.

2. Neunhäuserer $\mathrm{C}$, Berreck $\mathrm{M}$, Insam $\mathrm{H}$. Remediation of soils contaminated with molybdenum using soil amendments and phytoremediation. Water Air Soil Pollut. 2001;128(1-2):85-96.

3. LeGendre GR, Runnells DD. Removal of dissolved molybdenum from wastewaters by precipitates of ferric iron. Environ Sci Technol. 1975;9(8):744-9.

4. Biswas KC, Woodards NA, Xu H, Barton LL. Reduction of molybdate by sulfate-reducing bacteria. BioMetals. 2009;22(1):131-9.

5. Yu C, Xu S, Gang M, Chen G, Zhou L. Molybdenum pollution and speciation in Nver river sediments impacted with Mo mining activities in Western Liaoning, northeast China. Int $J$ Environ Res. 2011;5(1):205-12.

6. Heba H, Abuzinadah O, Al-Hamadi M, Al-Nedhary A, Zeid IA, Saini K, et al. Detection of heavy metal contamination in greasy grouper (Epinephelus tauvina) and striped mackerel (Rastrelliger kanagurta) from Al-Hodeidah, Red Sea coast of Yemen. J Food Agric Environ. 2014;12(2):845-50.

7. Yamaguchi S, Miura C, Ito A, Agusa T, Iwata H, Tanabe S, et al. Effects of lead, molybdenum, rubidium, arsenic and organochlorines on spermatogenesis in fish: Monitoring at Mekong Delta area and in vitro experiment. Aquat Toxicol. 2007;83(1):4351.

8. Meeker JD, Rossano MG, Protas B, Diamond MP, Puscheck E, Daly D, et al. Cadmium, lead, and other metals in relation to semen quality: Human evidence for molybdenum as a male reproductive toxicant. Environ Health Perspect. 2008;116(11):1473-9.

9. Zhai X-W, Zhang Y-L, Qi Q, Bai Y, Chen X-L, Jin L-J, et al. Effects of molybdenum on sperm quality and testis oxidative stress. Syst Biol Reprod Med. 2013;59(5):251-5.

10. Shukor MY, Syed MA. Microbiological reduction of hexavalent molybdenum to molybdenum blue. In: Mendez-Vilas A, editor. Current Research, Technology and Education Topics in Applied Microbiology and Microbial Biotechnology. Badajoz, Spain: Formatex Research Center; 2010. (Microbiology Book Series; vol. 2).

11. Othman AR, Bakar NA, Halmi MIE, Johari WLW, Ahmad SA, Jirangon $\mathrm{H}$, et al. Kinetics of molybdenum reduction to molybdenum blue by Bacillus sp. strain A.rzi. BioMed Res Int. 2013;2013.

12. Masdor N, Abd Shukor MS, Khan A, Bin Halmi MIE, Abdullah SRS, Shamaan NA, et al. Isolation and characterization of a molybdenum-reducing and SDS- degrading Klebsiella oxytoca strain Aft-7 and its bioremediation application in the environment. Biodiversitas. 2015;16(2):238-46.

13. Herold DA, Rodeheaver GT, Bellamy WT, Fitton LA, Bruns DE, Edlich RF. Toxicity of topical polyethylene glycol. Toxicol Appl Pharmacol. 1982;65(2):329-35.

14. Traverso-Soto JM, Rojas-Ojeda P, Sanz JL, González-Mazo E, Lara-Martín PA. Anaerobic degradation of alcohol ethoxylates and polyethylene glycols in marine sediments. Sci Total Environ. 2016;544:118-24.

15. Watanabe M, Kawai F. Study on biodegradation process of polyethylene glycol with exponential growth of microbial population. Vol. 52. 2010. 145-157 p.

16. Payne WJ, Williams JP, Mayberry WR. Primary alcohol sulfatase in a Pseudomonas species. Appl Microbiol. 1965;13(5):698-701.

17. Dwyer DF, Tiedje JM. Degradation of ethylene glycol and polyethylene glycols by methanogenic consortia. Appl Environ Microbiol. 1983;46(1):185-90

18. Kawai F, Enokibara S. Symbiotic degradation of polyethylene glycol (PEG) 20,000-phthalate polyester by phthalate ester- and PEG 20,000-utilizing bacteria. J Ferment Bioeng. 1996;82(6):5759.

19. Bakr MA, Ali MM, Sarkar PK. Synthesis and biodegradation of succinic acid-glycerol-polyethylene glycol-200 copolymer. J Polym Mater. 1997;14(3):251-5.

20. Kohlweyer U, Thiemer B, Schräder T, Andreesen JR. Tetrahydrofuran degradation by a newly isolated culture of Pseudonocardia sp. strain K1. FEMS Microbiol Lett. 2000;186(2):301-6.

21. Huang Y-L, Li Q-B, Deng X, Lu Y-H, Liao X-K, Hong M-Y, et al. Aerobic and anaerobic biodegradation of polyethylene glycols using sludge microbes. Process Biochem. 2005;40(1):207-11.

22. Pan L, Gu J-D. Characterization of aerobic bacteria involved in degrading polyethylene glycol (PEG)-3400 obtained by plating and enrichment culture techniques. J Polym Environ. 2007;15(1):5765 .

23. Bernhard M, Eubeler JP, Zok S, Knepper TP. Aerobic biodegradation of polyethylene glycols of different molecular weights in wastewater and seawater. Water Res. 2008;42(19):4791-801.

24. Marchal R, Nicolau E, Ballaguet J-P, Bertoncini F. Biodegradability of polyethylene glycol 400 by complex microfloras. Int Biodeterior Biodegrad. 2008;62(4):384-90.

25. Jiang X, Yang Y, Peng X, Tan X, Dai S, Zeng Q. Screening and degradation characteristics of bacteria degrading polyethylene glycol. Chin J Appl Environ Biol. 2013;19(5):857-61. 
26. Shukor MS, Shukor MY. A microplate format for characterizing the growth of molybdenum-reducing bacteria. J Environ Microbiol Toxicol. 2014;2(2):42-4.

27. Shukor MY, Lee CH, Omar I, Karim MIA, Syed MA, Shamaan NA. Isolation and characterization of a molybdenum-reducing enzyme in Enterobacter cloacae strain 48. Pertanika J Sci Technol. 2003;11(2):261-72.

28. Sims GEC, Snape TJ. A method for the estimation of polyethylene glycol in plasma protein fractions. Anal Biochem. 1980;107(1):603.

29. Zwietering MH, Jongenburger I, Rombouts FM, Van't Riet K. Modeling of the bacterial growth curve. Appl Environ Microbiol. 1990;56(6):1875-81.

30. Runnells DD, Kaback DS, Thurman EM. Geochemistry and sampling of molybdenum in sediments, soils, and plants in Colorado. In: Chappel WR, Peterson KK, editors. Molybdenum in the environment. New York: Marcel and Dekker, Inc.; 1976.

31. Capaldi A, Proskauer B. Beiträge zur Kenntniss der Säurebildung bei Typhus-bacillen und Bacterium coli - Eine differentialdiagnostische Studie. Z Für Hyg Infect. 1896;23(3):452-74.

32. Jan A. La reduction biologique du molybdate d'ammonium par les bactéries du genre Serratia (The biological reduction of ammonium molybdate by the bacteria of the Serratia kind). Bull Sci Pharmacol. 1939;46:336-9.

33. Bautista EM, Alexander M. Reduction of inorganic compounds by soil microorganisms. Soil Sci Soc Am Proc. 1972;36:918-20.

34. Campbell AM, Del Campillo-Campbell A, Villaret DB. Molybdate reduction by Escherichia coli K-12 and its chl mutants. Proc Natl Acad Sci U S A. 1985;82(1):227-31.

35. Ghani B, Takai M, Hisham NZ, Kishimoto N, Ismail AKM, Tano $\mathrm{T}$, et al. Isolation and characterization of a $\mathrm{Mo}^{6+}$-reducing bacterium. Appl Environ Microbiol. 1993;59(4):1176-80.

36. Marchal JG, Gerard TH. Etude du pouvoir reducteur de quelque souches de colibacille sur le molybdate d'ammoniaque. Trav Lab Microbiol Fac Pharm Nancy. 1948;16:11-23.

37. Woolfolk CA, Whitely HR. Reduction of inorganic compounds with molecular hydrogen by Micrococcus lactilyticus. I. Stoichiometry with compounds of arsenic, selenium, tellurium, transition and other elements. J Bacteriol. 1962;84:647-58.

38. Sabullah MK, Rahman MF, Ahmad SA, Sulaiman MR, Shukor MS, Shamaan NA, et al. Isolation and characterization of a molybdenum-reducing and glyphosate-degrading Klebsiella oxytoca strain Saw-5 in soils from sarawak. Agrivita. 2016;38(1):113.

39. Ibrahim Y, Abdel-Mongy M, Shukor MS, Hussein S, Ling APK, Shukor MY. Characterization of a molybdenum-reducing bacterium with the ability to degrade phenol, isolated in soils from egypt. Biotechnologia. 2015;96(3):234-45.

40. Abo-Shakeer LKA, Ahmad SA, Shukor MY, Shamaan NA, Syed MA. Isolation and characterization of a molybdenum-reducing Bacillus pumilus strain lbna. J Environ Microbiol Toxicol. 2013;1(1):9-14.

41. Ahmad SA, Shukor MY, Shamaan NA, Mac Cormack WP, Syed MA. Molybdate reduction to molybdenum blue by an Antarctic bacterium. BioMed Res Int. 2013;2013.

42. Lim HK, Syed MA, Shukor MY. Reduction of molybdate to molybdenum blue by Klebsiella sp. strain hkeem. J Basic Microbiol. 2012;52(3):296-305.

43. Shukor MY, Ahmad SA, Nadzir MMM, Abdullah MP, Shamaan NA, Syed MA. Molybdate reduction by Pseudomonas sp. strain DRY2. J Appl Microbiol. 2010;108(6):2050-8.

44. Shukor MY, Rahman MF, Suhaili Z, Shamaan NA, Syed MA. Hexavalent molybdenum reduction to Mo-blue by Acinetobacter calcoaceticus. Folia Microbiol (Praha). 2010;55(2):137-43.

45. Yunus SM, Hamim HM, Anas OM, Aripin SN, Arif SM. Mo (VI) reduction to molybdenum blue by Serratia marcescens strain Dr. Y9. Pol J Microbiol. 2009;58(2):141-7.

46. Shukor MY, Rahman MF, Suhaili Z, Shamaan NA, Syed MA. Bacterial reduction of hexavalent molybdenum to molybdenum blue. World J Microbiol Biotechnol. 2009;25(7):1225-34

47. Shukor MY, Rahman MF, Shamaan NA, Syed MS. Reduction of molybdate to molybdenum blue by Enterobacter sp. strain Dr.Y13. J Basic Microbiol. 2009;49(SUPPL. 1):S43-54.
48. Rahman MFA, Shukor MY, Suhaili Z, Mustafa S, Shamaan NA Syed MA. Reduction of Mo(VI) by the bacterium Serratia sp. strain DRY5. J Environ Biol. 2009;30(1):65-72.

49. Shukor MY, Habib SHM, Rahman MFA, Jirangon H, Abdullah MPA, Shamaan NA, et al. Hexavalent molybdenum reduction to molybdenum blue by $S$. marcescens strain Dr. Y6. Appl Biochem Biotechnol. 2008;149(1):33-43.

50. Steiert JG, Pignatello JJ, Crawford RL. Degradation of chlorinated phenols by a pentachlorophenol-degrading bacterium. Appl Environ Microbiol. 1987;53(5):907-10.

51. Chang YC, Nawata A, Jung K, Kikuchi S. Isolation and characterization of an arsenate-reducing bacterium and its application for arsenic extraction from contaminated soil. J Ind Microbiol Biotechnol. 2012;39(1):37-44.

52. Keyhan M, Ackerley DF, Matin A. Targets of improvement in bacterial chromate bioremediation. In: Pellei M, Porta A, editors. Remediation of Contaminated Sediments. Columbus, OH: Battelle Press; 2003.

53. Shukor MY, Rahman MFA, Shamaan NA, Lee CH, Karim MIA, Syed MA. An improved enzyme assay for molybdenum-reducing activity in bacteria. Appl Biochem Biotechnol. 2008;144(3):293300 .

54. Shukor MY, Halmi MIE, Rahman MFA, Shamaan NA, Syed MA Molybdenum reduction to molybdenum blue in Serratia sp. strain DRY5 is catalyzed by a novel molybdenum-reducing enzyme. BioMed Res Int. 2014;2014.

55. Zhang Y, Okeke BC, Jr WTF. Bacterial reduction of selenate to elemental selenium utilizing molasses as a carbon source. Bioresour Technol. 2008;99(5):1267-73.

56. Ahmad WA, Wan Ahmad WH, Karim NA, Santhana Raj AS Zakaria ZA. Cr(VI) reduction in naturally rich growth medium and sugarcane bagasse by Acinetobacter haemolyticus. Int Biodeterior Biodegrad. 2013;85:571-6.

57. Fujita M, Ike M, Nishimoto S, Takahashi K, Kashiwa M. Isolation and characterization of a novel selenate-reducing bacterium, Bacillus sp. SF-1. J Ferment Bioeng. 1997;83(6):517-22.

58. Antipov AN, Lyalikova NN, Khijniak TV, L'vov NP. Vanadate reduction by molybdenum-free dissimilatory nitrate reductases from vanadate-reducing bacteria. IUBMB Life. 2000;50(1):39-42.

59. Stone J, Stetler L. Environmental Impacts from the North Cave Hills Abandoned Uranium Mines, South Dakota. In: Merkel BroderJ, Hasche-Berger A, editors. Uranium, Mining and Hydrogeology [Internet]. Springer Berlin Heidelberg; 2008. p. 37180. Available from: http://dx.doi.org/10.1007/978-3-540-87746248

60. Chai B, Wu Y, Liu P, Liu B, Gao M. Isolation and phosphatesolubilizing ability of a fungus, Penicillium sp. from soil of an alum mine. J Basic Microbiol. 2011;51(1):5-14.

61. Anu M, Salom Gnana TV, Reshma JK. Simultaneous phenol degradation and chromium (VI) reduction by bacterial isolates. Res J Biotechnol. 2010;5(1):46-9.

62. Haines JR, Alexander M. Microbial degradation of polyethylene glycols. J Appl Microbiol. 1975;29(5):621-5.

63. Kawai F, Takeuchi M. Taxonomical position of newly isolated polyethylene glycol-utilizing bacteria. J Ferment Bioeng. 1996;82(5):492-4

64. Fincher EL, Payne WJ. Bacterial utilization of ether glycols. Appl Microbiol. 1962;10:542-7.

65. Schink B, Stieb M. Fermentative degradation of polyethylene glycol by a strictly anaerobic, gram-negative, nonsporeforming bacterium, Pelobacter venetianus sp. nov. Appl Environ Microbiol. 1983;45(6):1905-13.

66. Kawai F, Yamanaka H. Biodegradation of polyethylene glycol by symbiotic mixed culture (obligate mutualism). Arch Microbiol. 1986;146(2):125-9.

67. Schramm E, Schink B. Ether-cleaving enzyme and diol dehydratase involved in anaerobic polyethylene glycol degradation by a new Acetobacterium sp. Biodegradation. 1991;2(2):71-9. 